\title{
OUR SPECIAL ISSUE
}

In December 1993, the Australian and New Zealand History of Education Society held a joint conference with the Canadian History of Education Association/Association canadienne d'histoire de l'education, at Ormond College in the University of Melbourne. To commemorate this remarkable event in the lives of the two societies, and with the concurrence of the organizers of the conference, the editors of the History of Education Review and of Historical Studies in Education/Revue d'histoire de l'éducation agreed to publish a collection of articles drawn from the conference papers, to appear as the third, extraordinary, number for 1994 of each of the journals.

This special issue, number 3 of 1994, is now before you. It was edited in Australia and produced in Canada.

One of the themes of the joint conference was 'State Formation and Education,' and there were many good papers on that subject. But, as is usual at conferences, there were papers on a wide variety of themes. Some participants, for example, inspired by 1993 having been declared the Year of Indigenous Peoples, gave papers on that theme; others presented work on sub-themes as diverse as education and women's history, teachers and the state, and curriculum history. (A list of papers presented at the conference will be found at the end of this volume.) From this wealth of material, then, the editors have made a selection of ten papers, a handful picked from the dozens presented during those four conference days, which they hope will serve to hint at the scholarly riches that were displayed in Melbourne.

The first three articles, by Green, Vick, and Houston respectively, deal with the main conference theme. The next two, those by Selleck and Hogan, are concerned with the history of universities. Hogan's article leads on to the next two, on Catholic education, by Smyth and Condon (his ANZHES Presidential Address). The religious theme is pursued in Fitzgerald's article on the role of female missionaries in Maori education; and this serves to introduce the last two articles, that by Reynolds and Smaller on gender in teaching, and that by Weiss on Aboriginal education.

We hope that those who attended the conference in Melbourne will be pleased to read some of the papers that they heard there, and that those who did 
not attend will gather from what they read now, something of the excitement of the event.

Bob Petersen

Geoff Sherington
Rebecca Coulter

Bob Gidney

Ruby Heap

Wyn Millar 